УДК 7.025 .4

https://doi.org/10.24852/2587-6112.2021.6.315.324

\title{
СРАВНЕНИЕ МЕТОДОВ СТАБИЛИЗАЦИИ АРХЕОЛОГИЧЕСКИХ ПРЕДМЕТОВ ИЗ МЕДНЫХ СПЛАВОВ НА ПРИМЕРЕ МОНЕТ ХЕРСОНЕСА ТАВРИЧЕСКОГО
}

\author{
(C) 2021 г. Е.В. Струкова
}

В статье на примере нумизматических находок из раскопок Херсонеса Таврического рассмотрены основные методы стабилизации медных сплавов. В ходе этой работы монеты в зависимости от их сохранности и применяемых методов были разделены на семь групп. В результате проделанной работы были сделаны выводы по поводу эффективности применяемых методов. Стало ясно, что не все предметы из медных сплавов нуждаются в стабилизации. Обработка бензотриазолом может использоваться избирательно, с соблюдением необходимых мер безопасности и с обязательной проверкой результата. Метод глубокой промывки эффективен только для предметов, неглубоко пораженных активной коррозией. Обработка танином более эффективна по отношению к предметам, где хлористая медь осаждается по границам зерен металла. Обработка оксидом серебра доступна и эффективна, но при этом изменяется цвет поверхности предмета. При методе Розенберга также меняется цвет поверхности предметов. Комбинирование методов обработки танином и оксидом серебра показало высокую эффективность стабилизации и замедления коррозионных процессов. Однако это требует более пристального последующего наблюдения за предметами.

Ключевые слова: археологические предметы, Херсонес Таврический, консервация находок, стабилизация металла, медные сплавы, нумизматика, эффективность методов консервации.

\section{THE COMPARISON OF STABILIZATION METHODS FOR COPPER ALLOY ARCHAEOLOGICAL OBJECTS ON THE EXAMPLE OF THE COINS FROM TAURIC CHERSONESOS}

\section{E. V. Strukova}

The paper reviews the main methods of stabilizing copper alloys using the example of the numismatic finds from the excavations of Tauric Chersonesos. In the course of this work, the coins were subdivided into seven groups depending on their preservation level and the methods applied. As a result of the completed work, conclusions were made on the efficiency of the methods applied. It became obvious that not all copper alloy items require stabilization. The benzotriazole treatment can be used selectively, with adherence to the necessary safety measures and mandatory verification of the result. The deep rinsing method is only effective for objects shallowly affected by active corrosion. The tannin treatment is more effective for items where copper chloride is deposited along the metal grain boundaries. The silver oxide treatment is affordable and effective, but it changes the colour of the object's surface. The Rosenberg method also changes the colour of the surface of the objects. A combination of tannin and silver oxide treatment has shown high efficiency of stabilization and reduction in the rate of corrosion processes. However, this requires closer follow-up observation of the objects.

Keywords: archaeological objects, Tauric Chersonesos, conservation of finds, metal stabilization, copper alloys, numismatics, efficiency of conservation methods.

Херсонес Таврический - древнегреческий город-полис, который был основан на завершающем этапе Великой греческой колонизации на юго-западном берегу Крымского полуострова переселенцами из Гераклеи Понтийской. Этот город просуществовал долгое время - почти две тысячи лет, оставив после себя богатое историческое и археологическое наследие. Первые раскопки на месте «Русских Помпей» (так несколько позже назвала Херсонес графиня П.С. Уварова) были начаты в 1827 году и продолжаются по сей день. Почти уже 200 лет археологические исследования Херсонесского городища и его хоры дают богатый научный материал, основанный на разнообразных находках: строительные остатки разнообразных сооружений, захоронения и погребальный инвентарь некрополя, керамические комплексы разных хронологических периодов. Среди этого ряда присутствуют и изделия из металлов: железа, различных медных сплавов, серебра и, изредка, золота. Предметы из медных сплавов представлены ключами, иглами, крючками, спица- 
ми и другими изделиями, но самая большая группа - это нумизматический материал.

Художник-реставратор высшей категории С.Г. Буршнева выделяет три группы сохранности археологических медных сплавов в зависимости от погребенных условий (Буршнева, 2016, с. 39-45). Большинство монет Херсонеса Таврического относятся к группе сохранности А. Характерной особенностью этой группы является наличие на предметах активной коррозии. Активная коррозия медных сплавов развивается из-за наличия в окружающей среде большого количества катионов хлора, которые в условиях Причерноморья образуют с медью малоустойчивое соединение - хлористую медь, или минерал нантокит.

Хлористая медь - серое плотное воскообразное вещество - является крайне неустойчивым соединением и при наличии кислорода и влажности переходит в гидроксихлориды меди - сыпучий порошок зеленого цвета, минералы атакамит и/или паратакамит. Этот процесс называют бронзовой болезнью, а образование на поверхности основной хлорной меди в форме порошка служит указанием на наличие активных коррозионных процессов (Калиш, 1966, с. 72-97; Калиш, 1969, с. 125-148).

Поражения археологических находок активной коррозией могут быть точечными, локальными, обширными и сплошными. Хлористая медь может высаживаться по границам зерен металла в процессе межкристаллитной коррозии - в условиях повышенной влажности активная коррозия на таких предметах проявляет себя в виде небольших влажных капель, окрашенных в ярко-зеленый цвет. На сильно минерализованных монетах хлористая медь может образовывать «линзы» под первичной минеральной коркой, состоящей из оксида меди куприта, реагируя с кислородом и влагой, проникающими через микротрещины минеральной корки. В результате хлористая медь превращается в гидроксихлорид меди и выступает на поверхность предмета, часто провоцируя отслоение первичной минеральной корки с имеющимся на ней изображением; при этом происходит активное разрушение металлического ядра. Известны случаи, когда основные хлориды меди полностью покрывают всю поверхность монеты.
Несмотря на то, что предметы с разным развитием коррозионных процессов имеют отличные друг от друга и характерные для каждого типа развития внешние признаки, не всегда возможно определить наличие очагов активной коррозии визуальным способом. Одним из лабораторных методов тестирования предметов из медных сплавов на наличие активной коррозии является тестирование во влажной камере. Влажная камера (камера Розенберга) представляет собой герметичное пространство со $100 \%$ влажностью при $20^{\circ} \mathrm{C}$. После суточной выдержки во влажной камере на месте очагов хлористой меди появляются голубовато-зеленые капли влаги или светло-зеленые пятна (Минжулин, 1992, с. 45). Другой метод - определение наличия ионов хлора в водной вытяжке - применяется в основном в процессе стабилизации активной коррозии промывочными методами.

Процесс стабилизации активной коррозии на археологическом металле предполагает преобразование и замену неустойчивых химических соединений на более устойчивые - стабильные, а также консервацию или запечатывание (изоляцию) нестабильных соединений и очагов коррозии (Минжулин, 1992, с. 30). Известны различные методы стабилизации медных сплавов. Их выбор для того или иного предмета определяется различными факторами: степенью сохранности памятника, степенью эффективности метода и его доступностью. Рассмотрим некоторые из них.

Одним из таких методов является метод глубокой промывки, или метод Р.М. Органа. Суть метода заключается в вымывании хлоридов из микротрещин и капилляров металла и коррозионной корки путем чередования погружений в горячую и холодную воду (Плендерлис, 1964, с. 18; Шемаханская 2015 , с. 180). Промывка осуществляется до тех пор, пока в промывочной воде не перестанет фиксироваться наличие ионов хлора. Мониторинг за изменением количества хлора производится либо с помощью специальных кондуктометров, определяющих количество хлора в промывочной воде (количественный анализ), либо с помощью раствора азотнокислого серебра (качественный анализ) ${ }^{1}$. Метод стабилизации P.М. Органа опубликован практически во всех методических пособиях и признан достаточно эффективным. 
Другой метод, нередко применяемый для остановки активных коррозионных процессов - метод обработки бензотриазолом ${ }^{2}$ (БТА). Этот метод стал применяться с 1967 г. в зарубежной реставрации, а несколько позже и в отечественной. Для обработки БТА предмет сначала очищают от продуктов коррозии, вычищают очаги активной коррозии, а затем погружают в 3\% раствор БТА в этиловом спирте на сутки. После этого экспонат высушивают на открытом воздухе и, если не возникают новые очаги коррозии, осуществляют контрольную проверку во влажной камере. Если же в процессе сушки или контрольной проверки проявляются признаки активной коррозии, то процедуру повторяют (Шемаханская, 2015, с. 183-184). И.А. Минжулин рекомендовал обработку экспонатов из медных сплавов бензотриазолом только в качестве защитного покрытия. Согласно его методике, ингибирование поверхности осуществляется способом нанесения кистью 1\% раствора БТА в этаноле (Минжулин, 1992, с. 64).

Еще один способ стабилизации медных сплавов - обработка спиртовым или водноспиртовым раствором танина - уже более 10 лет практикуется в отечественной реставрации (Шемаханская, Леменовский, Лакшин, Брусова, 2008, с. 19-21). Перед обработкой раствором танина предмет очищается от продуктов коррозии, а затем погружается в раствор (200 танина/150 г этанола/1000 г $\mathrm{H}_{2} \mathrm{O}$ ) на один час. По истечении часа предмет вынимается, промывается в горячей дистиллированной воде, высушивается и снова погружается в раствор. Этот цикл повторяется несколько раз таким образом, чтобы суммарная обработка экспоната танином составила несколько часов, после чего предмет необходимо высушить и проверить результат во влажной камере (Шемаханская, 2015, с. 184-185). Если результат неудовлетворительный - следует повторить обработку.

Помимо перечисленных, известны еще два способа стабилизации активной коррозии медных сплавов, которые не нашли широкого применения в реставрационной практике, на наш взгляд - несколько незаслуженно. Оба эти способа применяются для обработки локальных очагов активной коррозии. Одним из них является метод Розенберга. Этот метод основан на реакции замещения: хлориды меди замещаются хлоридами алюминия. На обрабатываемый участок наносится смесь желатина с глицерином и накрывается алюминиевой фольгой, после чего предмет помещается во влажную камеру. В процессе реакции фольга чернеет, а образовавшееся черное вещество удаляется с помощью щетки под струей горячей воды. Данная процедура повторяется до тех пор, пока алюминий не перестанет вступать в реакцию (Мінжулін, 1998, с. 72).

Второй метод сходен с предыдущем по механизму действия, но в нем вместо алюминиевой фольги используется оксид серебра. В результате реакции хлористой меди с оксидом серебра образуются хлорид серебра и закись меди - устойчивые соединения, не разрушающие металл. Для обработки реставрируемого экспоната необходимо в первую очередь таким образом вычистить коррозионные язвы, чтобы оксид серебра контактировал именно с хлористой медью (нантокитом), расположенной иногда довольно глубоко. Затем на очищенный участок нанести оксид серебра (порошок темно-коричневого цвета) с помощью смоченной в этаноле заостренной деревянной палочки и поместить предмет во влажную камеру на 24 часа. Если в процессе тестирования во влажной камере активная коррозия проявит себя в виде влажных голубовато-зеленых пятен, то процедуру следует повторить. Поскольку эта обработка не всегда ведет к полному замещению хлористой меди хлоридом серебра, а часто просто изолирует («запечатывает») химически активное соединение, то за такими предметами требуется постоянное наблюдение (Шемаханская, 1989, c. 70-71).

Как показывает практика, не все перечисленные методы одинаково эффективны даже для групп однотипных предметов. Порой использование единственного метода или не ведет к стабилизации, или требует неоправданных временных затрат. За многие годы работы с археологическими бронзами Херсонеса Таврического мы пришли к выводу о необходимости комбинирования разных методов стабилизации для более быстрого и эффективного достижения результата.

В данной статье мы рассмотрим практическое применение вышеописанных методов и их комбинирование для стабилизации группы монет. Эти монеты были найдены в 
ходе археологических разведок Комплексной Херсонесской археологической экспедиции под руководством О.В. Шарова (Институт археологии РАН), Н.Ю. Новоселовой (Государственный Эрмитаж), С.Г. Рыжова и Д.А. Костромичева (Государственный музей-заповедник «Херсонес Таврический») на территории проектируемого историко-археологического парка «Херсонес Таврический».

В конце мая 2020 г. в реставрационную лабораторию музея-заповедника поступили 88 медных монет из шурфовок. Монеты относились к шурфам № 5, 6 и 21. Большая их часть имела визуальные признаки активной коррозии, и абсолютно все были покрыты почвенными наслоениями различной толщины. Монеты были механически расчищены и очищены, а затем разделены на несколько разноколичественных групп.

Группа 1. В эту группу вошло 16 монет, не имевших визуальных признаков активной коррозии. Проверка этих монет во влажной камере подтвердила стабильность металла 3 . Данным предметам стабилизация не понадобилась. Они были высушены в сушильном шкафу и покрыты полимерным консервирующим раствором.

Оставшиеся 69 монет имели ярко выраженные признаки активной коррозии, и в процессе механической расчистки выяснилось, что около трети от их количества имеют обширные образования хлористой меди. На некоторых экземплярах нантокит находился практически под всей площадью поверхности. Удалить такие скопления хлористой меди, не уничтожив предмет, не представлялось возможным, поэтому встал вопрос о подборе щадящих методов стабилизации. Все монеты с активной коррозией были разделены на шесть групп, к каждой группе применялись различные методы.

Группа 2. Вторую группу монет составили три экземпляра (рис. 1). После механической расчистки они были обработаны раствором бензотриазола согласно методике, которая наиболее часто практиковалась в реставрационной лаборатории Херсонеса до 2015 г. $^{4}$ Последовательность этой методики следующая.

Монеты были помещены в ацетон на 1 час для просушки и обезжиривания поверхности, а затем на 18 часов погружены в 3\% раствор БТА в этиловом спирте. По истечении этого времени предметы были просушены на открытом воздухе в течение одного часа и еще на час погружены в раствор БТА. После чего промыты от излишков БТА в двух ваннах этилового спирта по 1 часу каждая. Результат был проверен во влажной камере и оказался неудовлетворительным. По истечении менее 24 часов пребывания во влажной камере поверхность всех трех предметов была покрыта значительными по размеру влажными пятнами ярко-зеленого цвета, что свидетельствовало о высоком содержании ионов хлора и, соответственно, об активных коррозионных процессах (рис. 1: 1, 2-до расчистки; 3 - после обработки БТА; 4 - после влажной камеры).

В этом случае метод стабилизации с использованием БТА себя не оправдал.

Тем не менее мы не можем полностью списывать со счетов этот метод, потому что одна из монет ${ }^{5}-$ медный обол, принадлежащий чеканке Пантикапея, - изначально не имевшая признаков активной коррозии, но не прошедшая тестирование во влажной камере (оказалась покрыта россыпью микроскопических зеленых капелек), была также обработана раствором бензотриазола. Легенда монеты сохранилась полностью: Л. с. Голова безбородого сатира в венке влево. О. с. ПАN. Лук и стрела. Датируется 275-245 гг. до н. э. (Анохин, 1986, с. 141). Такая монета встречается очень часто при раскопках Пантикапея, в Херсонесе же она относится к редким единичным находкам. Данная монета - одна из немногих во всей партии имела хорошую сохранность, а дополнительную эстетическую привлекательность ей придавал красивый ровный темнозеленый цвет поверхности. Чтобы сохранить этот цвет, было решено применить обработку бензотриазолом, однако уже по методике, предложенной М.С. Шемаханской: погружение предмета в раствор 3\% БТА в этаноле под вакуумом на 24 часа (Шемаханская, 2015, с. 183). Мы не имели возможности поместить монету в вакуум, поэтому она была предварительно разогрета в сушильном шкафу при температуре 50 градусов в течение часа и помещена в раствор БТА на 24 часа. Через указанное время просушенный на открытом воздухе в течение часа предмет был перемещен во влажную камеру. Спустя одни сутки 

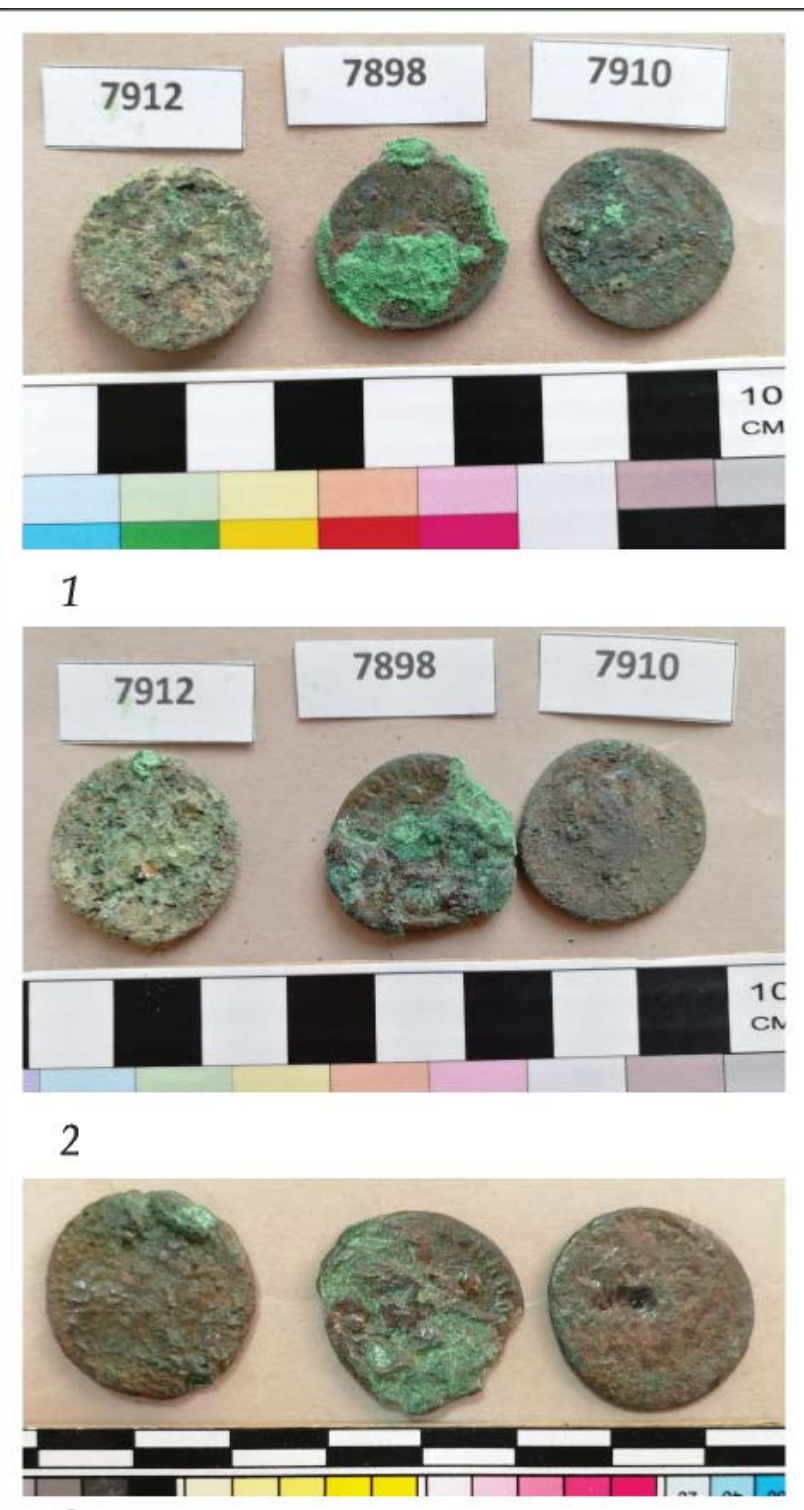

3

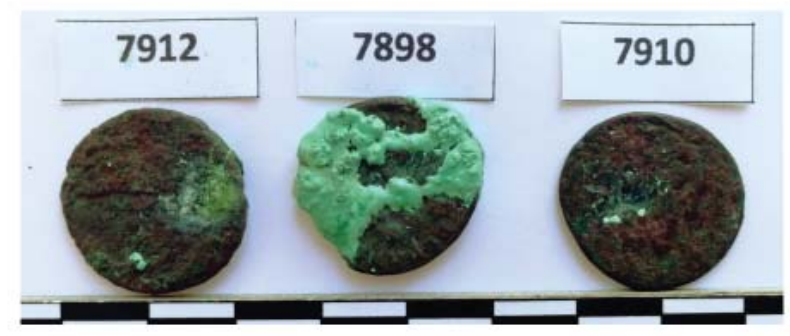

4

1. Группа 2. 1,2 - до расчистки; 3 - после обработки бензотриазолом; 4- после влажной камеры.

Рис. 1. Группа 2. Обработка Бензотриазолом. Фото С.В. Струковой.

Fig. 1. Group 2. Benzotriazole Treatment. Photo by S.V. Strukova. поверхность монеты не изменилась, зеленые влажные капли отсутствовали. Монета была просушена и законсервирована (рис. 2).

Группа 3. Следующим способом стабилизации, также не оправдавшим себя, как и обработка бензотриазолом в применении к столь глубоко пораженным предметам, стал метод глубокой промывки по М. Органу. Для стабилизации методом глубокой промывки были взяты три монеты со схожей степенью коррозионного поражения (рис. 3). Анализ водных проб с помощью азотнокислого серебра проводился через каждые 15-20 погружений 6 . С монетами было произведено 140 смен воды, но проба на наличие хлоридов осталась положительной (рис. 3: 1 -до промывки; 2 после промьвки).

Группа 4. В четвертую, самую многочисленную, группу вошли шесть монет после неудачной стабилизации из групп 2 и 3, а также еще 60 монет из рассматриваемой партии с визуальными признаками активной коррозии.

Данную группу было решено обрабатывать с помощью водно-спиртового раствора танина по методике, опубликованной М.С. Шемаханской. Монеты, очищенные от рыхлых коррозионных наслоений, погружались в раствор на несколько часов, затем промывались в горячей дистиллированной воде, высушивались, подогревались и снова погружались в раствор (Шемаханская, 2015, с. 184-185). Как правило, внешним результатом такой обработки является изменение цвета поверхности предметов - она всегда приобретает ровный темно-коричневый цвет. После 20 погружений проверка во влажной камере показала некоторые улучшения: пятна активной коррозии уменьшились до капель, снизилось их количество, но обработка была продолжена до тех пор, пока они не стали единичными. В процессе этой обработки монеты время от времени просушивались и проверялись во влажной камере, затем обработка продолжалась. В результате 39 монет этой группы перестали проявлять признаки активной коррозии при тестировании. Все эти монеты были высушены и законсервированы для дальнейшего хранения.

Группа 5(4). В эту группу перешли монеты, которые не стабилизировались до конца с помощью обработки раствором танина - 


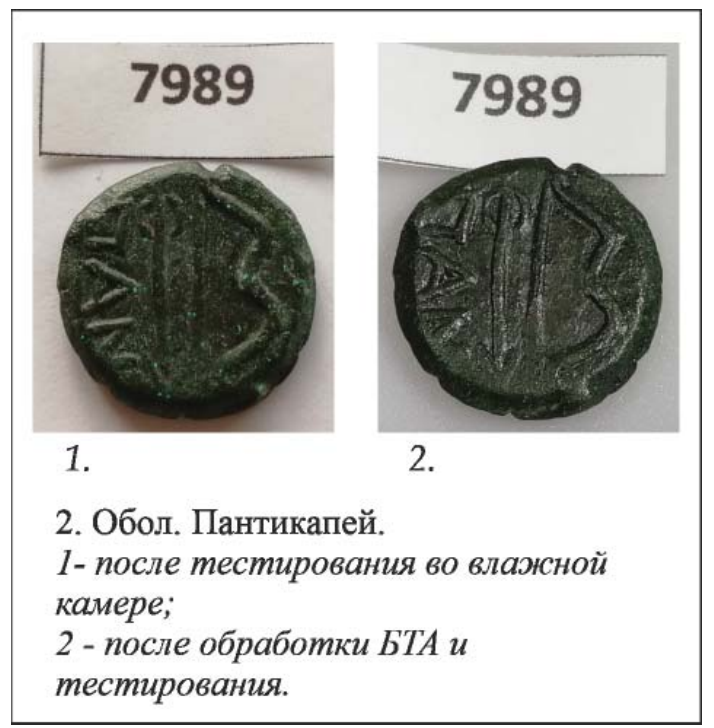

Рис. 2. Обол. Пантикапей. Обработка Бензотриазолом. Фото С.В. Струковой.

Fig. 2. Obol. Panticapaeum. Benzotriazole Treatment. Photo by S.V. Strukova.

27 монет. Когда положительная динамика обработки танином прекратилась, а активная коррозия продолжала проявлять себя во время тестирования, решено было продолжить стабилизацию методом локальной обработки, а именно - обработкой единичных оставшихся очагов активной коррозии оксидом серебра. Следуя этому методу, все продукты коррозии, после последнего тестирования во влажной камере, были тщательно вычищены. На очищенный участок наносился порошок оксида серебра с помощью деревянной палочки, предварительно смоченной в этиловом спирте (другой вариант нанесения - смешать немного порошка оксида с каплей этанола до образования пастообразной массы и втирать эту массу также деревянной палочкой). Обработанный таким образом предмет помещался на сутки во влажную камеру. Если по истечении этого времени на обработанной поверхности появлялись влажные зеленые точки, то процедура повторялась. Образовавшийся в результате реакции на поверхности нантокита хлорид серебра как бы «запечатывает» язву активной коррозии. Согласно нашим наблюдениям, предмет часто покрывается зелеными точками раньше истечения суток, и в этом случае лучше обрабатывать их по мере появления и обнаружения. В нашем случае на некоторых монетах зеленые капли появлялись в течение первых часов. Если отложить их обработку, можно потерять значительную часть поверхности предмета, поскольку все продукты коррозии, в том числе и образовавшиеся во влажной камере, перед каждой обработкой необходимо удалять. Главное, чтобы после последней обработки предмет наблюдался во влажной камере не менее суток. Метод зарекомендовал себя как достаточно эффективный, нетрудоемкий, малозатратный по времени, и расход реактива очень незначительный. В нашем случае обработка разных монет заняла от одних до четырех суток.

Группа 6. Эта группа представлена всего двумя монетами. Первоначально предполагалось, что они, как и пантикапейский обол, относятся к группе предметов без активной коррозии. Однако тестирование во влажной камере выявило несколько незначительных очагов. Эти две монеты были обработаны, как и монеты группы 5(4), т. е. с помощью оксида серебра, описанным выше способом. Для завершения обработки понадобилось всего двое суток.

Группа 7. В данную группу вошли три последние монеты из всей партии. Эти три монеты были обработаны по методу Розенберга. Обработка заняла два месяца и производилась следующим образом. Отдельные очаги активной коррозии (1 монета) и предметы целиком (2 монеты) были очищены и покрыты смесью, состоящей из желатина, глицерина и дистиллированной воды в пропорции: 120 г $\mathrm{H}_{2} \mathrm{O} / 20$ г желатина / 7 мл глицерина. Затем монеты оборачивались алюминиевой фольгой и помещались во влажную камеру. Через некоторое время (20-40 мин.) на фольге начинали появляться черные пятна, свидетельствующие о течении реакции (рис. 4: 3). Когда на реагирующих участках фольга полностью растворялась, ее удаляли с помощью щетки с коротким жестким синтетическим ворсом под струей горячей воды. Затем поверхность снова покрывалась желатиновой смесью, предмет оборачивался фольгой и помещался во влажную камеру. Первые несколько замен были сделаны в течение дня, затем реактивы заменялись раз в сутки, затем через сутки с половиной. Когда через последний указанный интервал признаки реакции не были обнаружены, обработка прекратилась. Монеты были промыты от желатиновой смеси, высушены и законсервированы. Поверхность всех трех монет, имевшая зеленоватый оттенок перед 

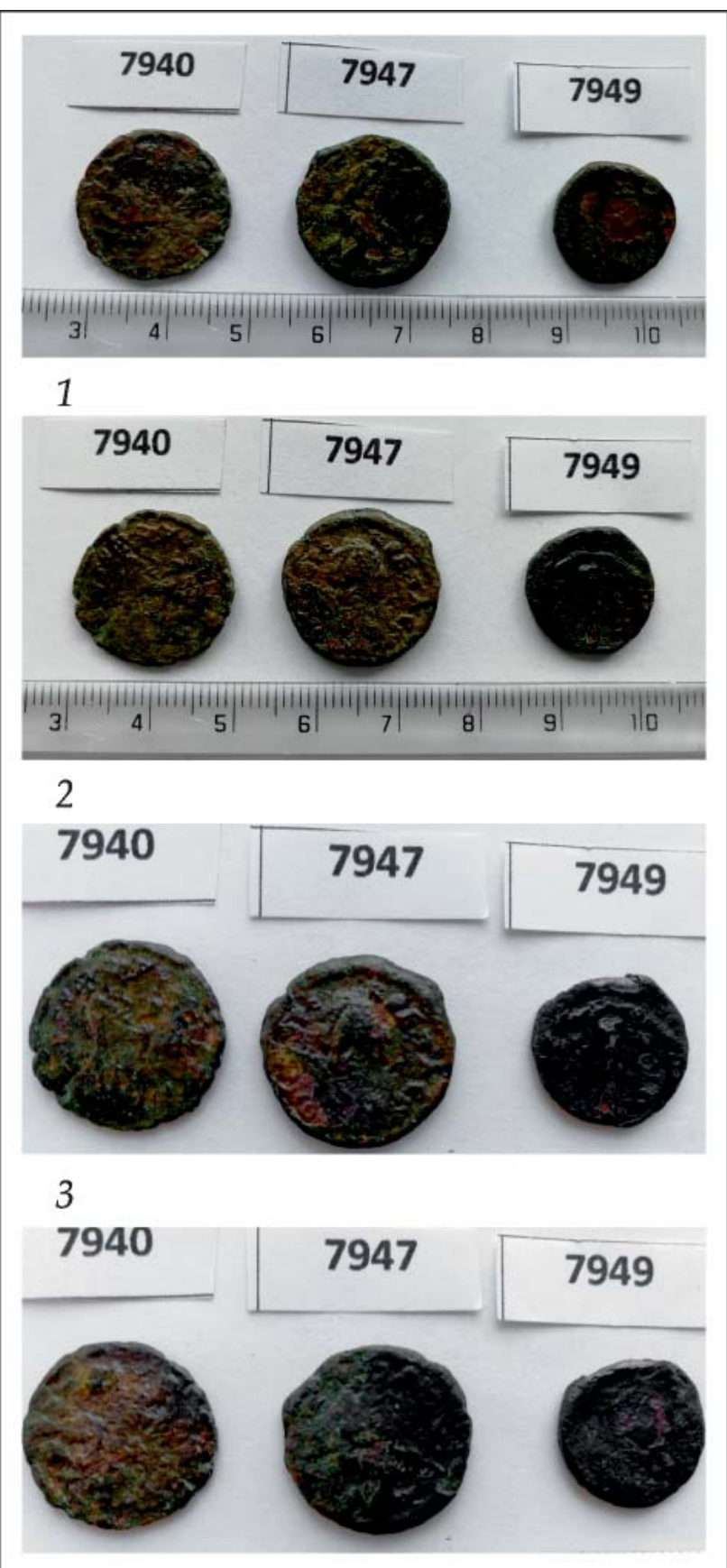

4

3. Группа 3. 1,2 - после расчистки; 3,4 - после промывки.

Рис. 3 Группа 3. Стабилизация методом глубокой промывки. Фото С.В. Струковой.

Fig. 3 Group 3. Stabilization using the deep rinsing method. Photo by S.V. Strukova. стабилизацией, приобрела ровный коричневый цвет (рис. 4).

Подводя итог работе над этой партией монет, можно сказать, что в ней оказались предметы как с глубокими коррозионными поражениями, так и с полным отсутствием активной коррозии. Поскольку 16 монет (группа 1), которым не понадобились стабилизационные мероприятия, почти все были из одного шурфа, можно с осторожностью предположить, что такую хорошую сохранность этим предметам обеспечил состав почвы (но это тема для будущих исследований). Монеты с обширными поражениями активной коррозией (группа 2 и группа 3) не удалось стабилизировать ни с помощью раствора бензотриазола, ни с помощью промывки в дистиллированной воде. В то же время 3\% раствор БТА в этаноле справился с активной коррозией на пантикапейском оболе, который проявил признаки активной коррозии только после тестирования. Обработка монеты бензотриазолом никак не изменила внешних эстетических данных монеты.

Хорошо зарекомендовала себя дальнейшая обработка этих монет с помощью водно-спиртового раствора танина. Количество очагов активной коррозии благодаря такой обработке было уменьшено многократно. И хотя не все из 66 монет, обработанных танином, полностью были стабилизированы и к ним в дальнейшем пришлось применить метод локальной стабилизации, тем не менее более половины монет группы 4 не нуждались в применении комбинации методов. Из всех монет, обрабатываемых только водно-спиртовым раствором танина, 38 в конце обработки показали хороший результат во влажной камере, и для них дополнительные стабилизационные мероприятия не потребовались. Поверхность всех монет, прошедших обработку водно-спиртовым раствором танина, приобрела ровный темно-коричневый цвет.

Перешедшие из группы 4 в группу 5(4) монеты и монеты группы 6 были обработаны оксидом серебра. Метод нетрудоемкий, не затратный по времени и средствам. Тем не менее есть у этого метода и слабые места. Во-первых, хлориды не удаляются, а запечатываются, поэтому за обработанными таким образом предметами необходимо постоянное наблюдение. Во-вторых, места обработ- 
ки приобретают коричневый цвет различных оттенков. В случае наличия у предмета ровной зеленой патины это выглядит не очень эстетично. Однако после предыдущей обработки танином этот недостаток не имеет значения. Как было уже сказано, танин делает цвет поверхности предмета темно-коричневым, и пятна, остающиеся от обработки оксидом, не выделяются.

Исходя из всего вышеизложенного можно сделать следующие выводы:

Не все предметы из медных сплавов нуждаются в стабилизации.

Метод обработки БТА имеет преимущество в том, что практически не изменяет цвет поверхности предмета и оказывает положительное действие в случае низкого содержания хлоридов в металле. Отрицательные факторы такого метода: неэффективен при высоком уровне хлора; реактив опасен для здоровья человека; высокая сложность утилизации в условиях обычной реставрационной лаборатории. В связи со всем вышеперечисленным данный метод не может широко применяться для стабилизации предметов из медных сплавов, но может использоваться избирательно, с соблюдением необходимых мер безопасности и с обязательной проверкой результата.

Метод глубокой промывки также эффективен только для предметов, неглубоко пораженных активной коррозией. Кипячение в дистиллированной воде может влиять на цвет поверхности предметов - делать цвета ярче и контрастнее. Неопасен для человека, специальная утилизация не требуется.

Метод обработки танином более эффективен по отношению к предметам, где хлористая медь осаждается по границам зерен металла, но и он не способен удалить хлорные соединения полностью в случае высокого содержания хлоридов. Поверхность предметов после использования танина меняет цвет, становясь коричневой. Безвреден для человека. Незатратен по времени и силам.

Метод обработки оксидом серебра не опасен для здоровья, доступен, эффективен. Не требует специальной утилизации и

Рис. 4. Группа 7. Обработка по методу Розенберга. Фото С.В. Струковой.

Fig. 4. Group 7. Processing using the Rosenberg method. Photo by S.V. Strukova.
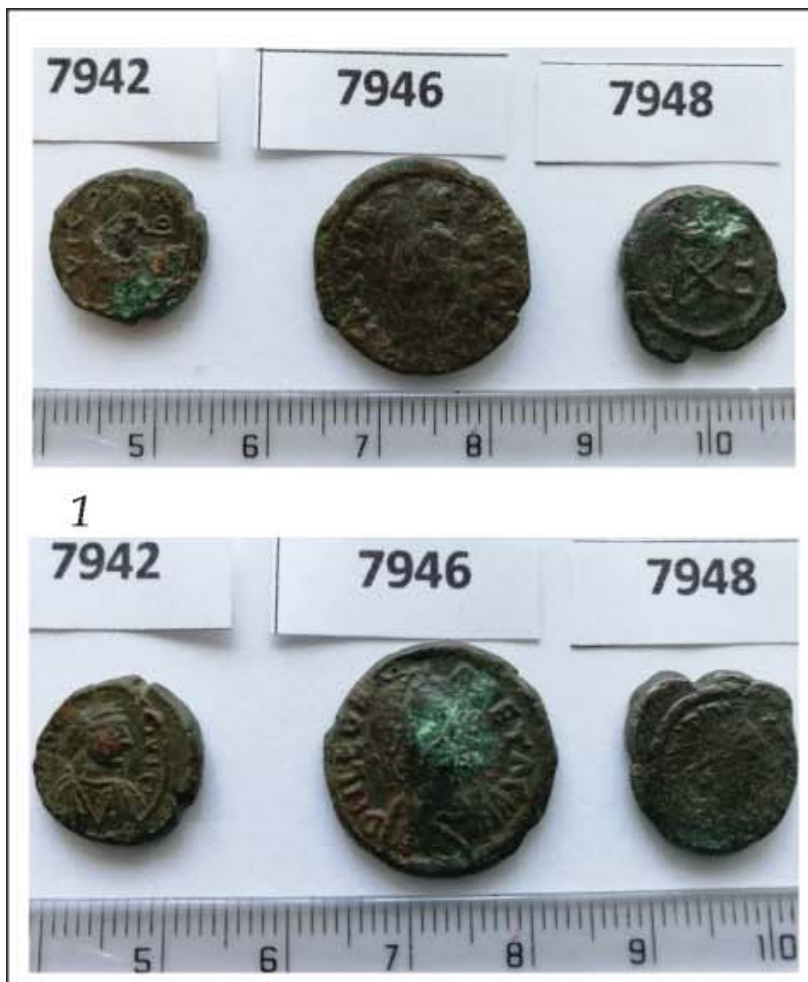

2
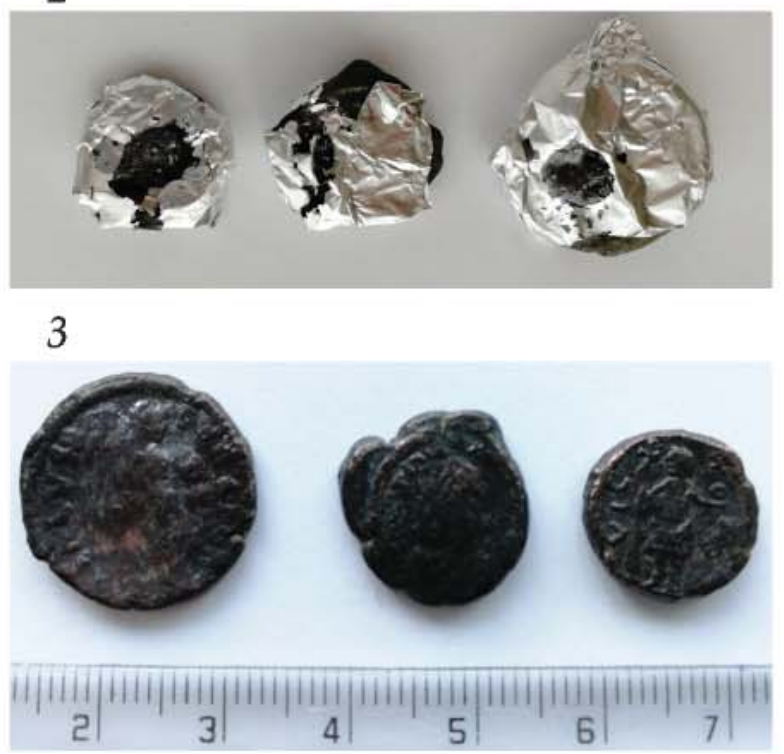

4

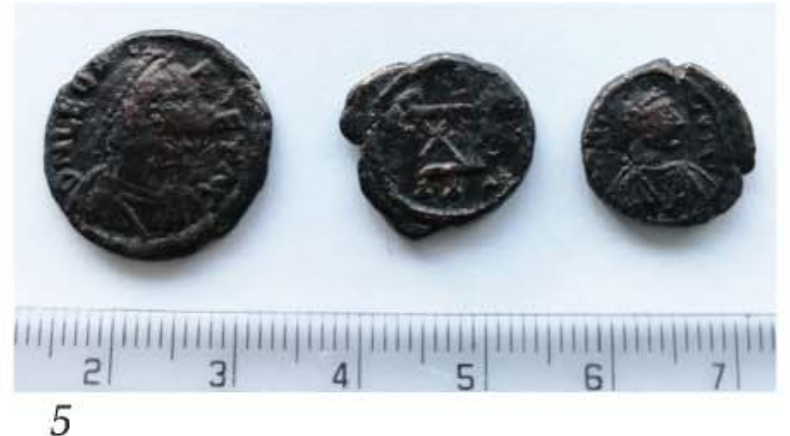
5

4. Группа 7. 1,2 - после расчистки; 3 - в прочессе обработки методом Розенберга;

4,5 - после реставрачии. 
не занимает длительного времени. Однако в процессе обработки изменяется цвет поверхности предмета - на местах обработки остаются коричневые пятна; требует более частого мониторинга при хранении.

Метод Розенберга неопасен для здоровья, эффективен, доступен, однако результатом его применения является пусть незначительное, но изменение цвета поверхности либо всего предмета, либо стабилизируемого участка. К тому же, в случае обширных поражений хлоридами, обработка этим методом занимает очень длительное время.
Комбинирование методов обработки танином и оксидом серебра показало высокую эффективность стабилизации и замедления коррозионных процессов для предметов, имеющих слабое металлическое ядро, окруженное широкими линзами хлористой меди. Так же как и обработка танином, оксид серебра окрашивает поверхность в коричневый цвет, но при комбинации этих методов цвет поверхности остается равномерным. Незатратен по времени, безвреден для человека. Однако требует более пристального последующего наблюдения за предметами.

\section{Примечания:}

${ }^{1}$ Качественный анализ на наличие хлора в водной вытяжке производится не только при промывке металлов, но и изделий из других материалов (керамика, камень) и описан практически во всех реставрационных методиках достаточно подробно (напр. см. Плендерлис, 1964, с. 18-19).

${ }^{2}$ Следует помнить, что по Паспорту безопасности GOST 30333-2007 от 16.02.2018, вещество БТА вредно при попадании внутрь или при вдыхании. Вызывает серьезное раздражение глаз. Вредно для водной флоры и фауны.

${ }^{3}$ Интересно заметить, что большинство из них было обнаружено в шурфе № 6, грунт - серый и темно-серый суглинок.

${ }^{4}$ C 2015 г. для стабилизации чаще используется спиртовой и водно-спиртовой раствор танина или метод глубокой промывки.

5 Эта монета не включена ни в одну из групп, поскольку отличается от всех остальных как по внешнему виду, так и по виду очагов коррозии после тестирования во влажной камере.

6 Стоит отметить, что этим методом мы пользовались и раннее. Он по продолжительности занимает определенное время, но обычно для вымывания хлора было достаточно от 15 до 40 погружений. Интересным следствием такой обработки является изменение цвета (цветов) предметов, напрямую зависящее от количества промывок - чем больше промывок, тем сильнее и контрастнее изменения.

\section{ЛИТЕРАТУРА}

Анохин В.А. Монетное дело Боспора. Киев: Наукова думка, 1986. 224 с.

Буршнева С.Г. Некоторые аспекты сохранности археологических находок из медных сплавов // Вестник Музея Археологии и Этнографии Пермского Предуралья. 2016. № 6. С. 39-45.

Калиш М.К. Рецидивная коррозия древних бронзовых предметов // Сообщения ВЦНИЛКР. № 17-18. М., 1966. С. 72-97.

Калиш М.К. Изменение древних бронз вследствие почвенной коррозии // Сообщения ВЦНИЛКР. № 24-25. М., 1969. С. 125-149.

Минжулин А.И. Введение в реставрацию металла. К., 1992.100 с.

Мінжулін О. І. Реставрація творів з металлу. К.: Спалах, 1998. 232 с.

Плендерлис Г. Дж. Консервация древностей и произведений искусства. М.: Советская Россия., 1964. $176 \mathrm{c}$.

Шемаханская М.С. Металлы и вещи: свойства, разрушение, реставрация. М.: Индрик, 2015. 288 с.

Шемаханская М.С., Леменовский Д.А., Лакшин Б.В., Брусова Г.П. Новые методы в реставрации археологического металла // Вестник реставрации музейных ценностей. 2008. №1(11). 64 с.

\section{Информация об авторе:}

Струкова Екатерина Валериевна, Художник-реставратор 1 категории, Отдел научной реставрации Государственного музея-заповедника «Херсонес Таврический», (г. Севастополь, Россия); Strukova76@mail.ru

\section{REFERENCES}

Anokhin, V. A. 1986. Monetnoe delo Bospora (Coinage of Bosporus). Kiev: "Naukova dumka" Publ. (in Russian).

Burshneva, S. G. 2016. In Vestnik Muzeia arkheologii i etnografii Permskogo Predural'ia (Bulletin of the Museum of Archaeology and Ethnography of the Perm Cis-Urals) 6, 39-45 (in Russian). 
Kalish, M. K. 1966. In Soobshcheniia VCNILKR (Proceedings of VTSNILKR) 17-18. 72-97 (in Russian).

Kalish, M. K. 1969. In Soobshcheniia VCNILKR (Proceedings of All-Union Central Research Laboratory for the Conservation and Restoration of Museum Objects) 24-25. 125-149 (in Russian).

Minzhulin, A. I. 1992. Vvedenie v restavratsiiu metalla (Introduction to Metal Restoration). Kiev (in Russian).

Minzhulin, A. I. 1998. Restavratsiia tvoriv z metallu (Restoration of Metal Objects). Kiev (in Ukranian).

Shemanskaia, M. S., Lemenovskii, D. A., Lakshin, B. V., Brusova, G. P. 2008. In Vestnik restavratsii muzeinykh tsennostei (Museum Object Restoration Bulletin) 12 (1), 64 (in Russian).

Shemanskaia, M. S. 2015. Metally $i$ veshchi: svoistva, razrushenie, restavratsiia (Metals and Objects: Properties, Destruction, Restoration). Moscow: "Indrik" Publ. (in Russian).

Plenderlis, G. J. 1964. Konservatsiia drevnostei i proizvedenii iskusstva (Conservation of Antiquities and Works of Art). Moscow: "Sovetskaia Rossia" Publ. (in Russian).

\section{About the Author:}

Strukova Ekaterina V. Metal conservator of the 1st category, The Satet Museum-Preserve "Tauric Chersonese". Drevnyaya str. 1., Sevastopol, 299045, Crimea, Russian Federation; Strukova76@mail.ru

Статья поступила в журнал 01.10.2021 г. Статья принята к публикации 01.12.2021 г. 